\title{
Suplementasi Konsentrat untuk Memperbaiki Body Condition Score (BCS) Sapi Induk Menjelang Dikawinkan
}

\author{
Concentrate Suplementation to Improve Body Condition Score (BCS) of Beef \\ Cows Before Breeding
}

\section{E. Mulyanti dan F. K. Keraf}

\author{
Balai Besar Pelatihan Peternakan Kupang \\ Jalan Timor Raya KM 17 Noelbaki, Kupang, Nusa Tenggara Timur, Indonesia \\ Corresponding e-mail : enimulyanti@gmail.com
}

\begin{abstract}
The insufficient nutrient was associated with suboptimal reproductive performance. To meet nutrient requirements, beef cows need fibrous feed, and they also need to concentrate supplementation in their diet. A research aimed to study the effect of concentrate supplementation on body condition score (BCS) used forty eight beef cows, consisted of 24 Ongole Crossbreds (PO) weighing 280,54 \pm 34,79 kg (CV 12,40\%) and 24 Simmental - PO crossbreds (SPO) weighing 357,29 $\pm 36,07 \mathrm{~kg}$ (CV 10,09\%). Basal feeds being used were fermented rice straw ad libitum and Napier grass $5.00 \%$ body weight (as fed). The experimental method used in this experiment was a completely randomized design in nested classification with 2 factors and 8 replications. The first factor was a breed of cow, i.e. PO and SPO. The second factor was the amount of concentrate supplementation in the diet $(11,82 \% \mathrm{CP}$ and $66,74 \% \mathrm{TDN})$, i.e. T0 : without concentrate, T1 : concentrate $0.50 \% \mathrm{BW}$ (as fed) and $\mathrm{T} 2$ : concentrate $1.00 \% \mathrm{BW}$ (as fed). The results of this research showed that breed of the cow did not have a significant effect on feed intake, daily gain, and body condition score (BCS) but diet had a significant effect $(\mathrm{P}<0,05)$. In conclusion, diet supplementation with a concentrate containing $11.82 \% \mathrm{CP}$ and $66.74 \% \mathrm{TDN}$ as much as $1 \% \mathrm{BW}$ gave the best body condition score of beef cows before mated.
\end{abstract}

Keywords : body condition score (BCS), beef cow, concentrate

\begin{abstract}
ABSTRAK
Penelitian dengan tujuan mengkaji suplementasi konsentrat terhadap skor kondisi tubuh atau body condition score (BCS) sapi potong induk telah dilaksanakan di Desa Pendoworejo, Kecamatan Girimulyo, Kabupaten Kulon Progo, Provinsi Daerah Istimewa Yogyakarta. Penelitian ini menggunakan 48 ekor sapi potong induk yang terdiri atas 24 ekor sapi Peranakan Ongole (PO) dengan rataan bobot badan (BB) 280,54 $\pm 34,79 \mathrm{~kg}$ (CV 12,40\%) dan 24 ekor sapi silangan Simmental - PO (SPO) dengan rataan BB 357,29 $\pm 36,07 \mathrm{~kg}$ (CV 10,09\%). Pakan dasar yang digunakan adalah jerami padi fermentasi ad libitum dan rumput gajah 5,00\% BB (bahan segar). Metode penelitian adalah eksperimental dengan Rancangan Acak Lengkap Pola Tersarang yang terdiri atas 2 faktor dan 8 ulangan. Faktor pertama adalah bangsa sapi, yaitu Peranakan Ongole (PO) dan persilangan Simmental - PO (SPO), dan faktor kedua adalah jumlah penambahan konsentrat dalam ransum (PK 11,82\% dan TDN 66,74\%), yaitu T0 : tanpa konsentrat, T1 : konsentrat 0,50\%BB (bahan segar), T2 : konsentrat 1,00\% BB (bahan segar). Hasil penelitian menunjukkan bahwa bangsa sapi tidak berpengaruh terhadap konsumsi pakan, $\mathrm{PBBH}$, sedangkan perlakuan ransum berpengaruh nyata $(\mathrm{P}<0,05)$. Kesimpulan dari penelitian ini adalah pemberian konsentrat dengan kadar PK 11,82\% dan TDN 66,74\% sebanyak 1\% dari bobot badan menghasilkan BCS yang paling ideal untuk sapi induk PO dan sapi induk silangan Simmental - PO pada saat menjelang dikawinkan.
\end{abstract}

Kata kunci : body condition score (BCS), sapi induk, konsentrat

\section{PENDAHULUAN}

Salah satu tujuan pembangunan pertanian adalah mewujudkan kedaulatan pangan dan kesejahteraan petani. Kedaulatan pangan pangan salah satunya diwujudkan melalui pencapaian swasembada pangan dan meningkatnya produksi daging. Kementerian Pertanian memfokuskan pembangunan pertanian pada tujuh komoditas strategis yaitu bawang merah, padi, jagung, kedelai, cabai, daging sapi, dan gula.

Dalam kaitannya dengan peningkatan produksi daging sapi, salah satu program Direktorat Jenderal Peternakan dan Kesehatan 
Hewan adalah peningkatan populasi yang dilakukan dengan peningkatan kelahiran dan penekanan kematian, melalui program Upaya Khusus Sapi Indukan Wajib Bunting (UPSUS SIWAB). UPSUS SIWAB bertujuan untuk mengoptimalkan potensi sapi induk- dalam menghasilkan pedet untuk mendukung peningakatan populasi sapi secara berkelanjutan. Untuk dapat bereproduksi dengan optimal, sapi induk harus dalam kondisi tubuh yang baik dan sehat. Sapi induk dengan kondisi tubuh yang tidak baik (terlalu kurus) beresiko mengalami gangguan reproduksi. Beberapa indikator terjadinya gangguan reproduksi dapat dilihat dari nilai service per conception $(\mathrm{S} / \mathrm{C})$ yang tinggi ( ideal $<$ $1,5)$, conception rate $(\mathrm{CR})$ yang rendah (ideal $>$ $60 \%$ ), calving interval (CI) yang panjang (ideal 12 bulan), kemajiran, dan rendahnya angka kelahiran (Ditjenak, 2016).

Kondisi tubuh sapi yang memburuk (terlalu kurus) dapat mengganggu fungsi tubuh secara keseluruhan, termasuk aktifitas reproduksi. Salah satu metode untuk penilaian kondisi tubuh sapi induk adalah Body Condition Score (BCS). BCS merupakan metode penilaian jumlah lemak yang menutupi tubuh seekor hewan, dan merupakan suatu alat yang penting dalam mengelola ternak sapi potong dan mengoptimalkan sumber daya pakan (NFACC, 2013), atau dengan kata lain BCS merupakan alat menjelaskan status nutrisi ternak (Wright et al. 1987). Pendugaan cadangan lemak tubuh dapat dilakukan secara subyektif dengan melihat (inspeksi) dan meraba (palpasi) (Edmonson et al., 1989). Dengan demikian, untuk meningkatkan penampilan reproduksinya, sapi induk dengan kondisi tubuh yang terlalu kurus perlu diberikan pakan yang sesuai untuk memperbaiki kondisi tubuhnya.

Pengukuran BCS menurut Edmonson et al. (1989) menggunakan skala 1-5, yaitu nilai 1 : sangat kurus, nilai 2 : kurus, nilai 3 : sedang, nilai 4 gemuk, serta nilai 5 : sangat gemuk. Diantara nilai-nilai utama itu terdapat nilai $0.25 ; 0,5 ; 0,75$ untuk menggambarkan nilai yang berada diantaranya. Menurut Ditjenak (2016), kelompok sapi dengan BCS kurang dari 2 mengalami kekurangan nutrisi yang selanjutnya dapat mengakibatkan sistem reproduksi yang tidak berfungsi secara optimal. Agar dapat sistem reproduksi dapat berfungsi secara optimal, BCS sapi induk seharusnya diatas atau sama dengan 2 . Menurut Tophianong et al., 2014, BCS ideal dari sapi betina yang akan di IB adalah 2,5 - 3 dari skala $1-5$.

\section{MATERI DAN METODE}

Penelitian ini menggunakan sapi induk sebayak 48 ekor terdiri atas bangsa Peranakan Ongole dengan rataan bobot 280,54 $\pm 34,79 \mathrm{~kg}$ (CV 12,40\%) dan silangan Simmental - PO dengan rataan bobot $357,29 \pm 36,07 \mathrm{~kg}$ (CV $10,09 \%$ ), masing-masing sebanyak 24 ekor, sudah beranak kedua atau ketiga, kondisi sehat dan tidak dalam keadaan bunting. Ternak-ternak sapi tersebut milik peternak di Desa Pendoworejo, Kecamatan Girimulyo, Kabupaten Kulon Progo, Provinsi Daerah Istimewa Yogyakarta. Sapi induk diberi pakan dasar berupa jerami fermentasi ad libitum dan rumput gajah sebanyak $5 \%$ bobot badan berdasarkan bahan segar.

Metode penelitian adalah eksperimental menggunakan Rancangan Acak Lengkap (RAL) Pola Tersarang (Kaps dan Lamberson, 2007) dengan dua faktor. Faktor pertama adalah bangsa sapi, yaitu PO dan silangan Simmental - PO, dan sebagai faktor kedua adalah perlakuan ransum, yaitu T0, T1 dan T2 yang tersarang dalam bangsa sapi. Setiap perlakuan ransum terdiri atas delapan ekor induk sapi sebagai ulangan. Perlakuan ransum yang diberikan meliputi :

T0 : Tanpa konsentrat

T1 : Konsentrat sebanyak $0,5 \%$ bobot badan.

$\mathrm{T} 2$ : Konsentrat sebanyak 1,0\% bobot badan.

Tabel 1. Komposisi kimia bahan pakan yang digunakan selama penelitian

\begin{tabular}{|c|c|c|c|c|c|c|c|}
\hline Bahan pakan & $\mathrm{BK}$ & $\mathrm{Abu}$ & PK & LK & SK & BETN & TDN \\
\hline & & & & $(6)$ & & & \\
\hline Rumput gajah ${ }^{1}$ & 17.67 & 11.54 & 9.68 & 1.93 & 32,38 & 44,48 & $55,01^{3}$ \\
\hline Jerami padi fermentasi ${ }^{2}$ & 77.56 & 17.75 & 13.81 & 1.29 & 22,81 & 44,34 & $54,40^{3}$ \\
\hline Konsentrat $^{1}$ & 88,32 & 10,73 & 11,82 & 8,13 & 17,76 & 49,49 & 66,74 \\
\hline
\end{tabular}

${ }^{1}$ Hasil analisa Lab. Teknologi Makanan Ternak Fapet UGM

${ }^{2}$ Hasil analisa Lab. Uji Teknologi Pangan dan Hasil Pertanian UGM 
Tahap persiapan penelitian dimulai dengan dengan menentukan ternak yang akan digunakan dalam penelitian sesuai kriteria yang ditetapkan, persiapan kandang dan perlengkapannya serta pengacakan ternak percobaan dalam tiga perlakuan ransum. Tahap pendahuluan diawali dengan pemberian obat cacing untuk 48 ekor sapi percobaan. Sapi-sapi tersebut diberi ransum perlakuan selama 10 hari dengan tujuan untuk untuk menghilangkan pengaruh pakan sebelumnya. Penimbangan ternak dilakukan pada akhir tahap pendahuluan, untuk mendapatkan data bobot badan awal, kemudian dilanjutkan dengan tahap pemberian perlakuan ransum.

Data yang dikumpulkan pada penelitian ini adalah konsumsi pakan yang meliputi konsumsi bahan kering (BK), konsumsi protein kasar (PK) dan konsumsi Total Digestible Nutrients (TDN); pertambahan bobot badan harian $(\mathrm{PBBH})$ dan skor kondisi tubuh atau body condition score (BCS). Konsumsi pakan diukur dengan cara menimbang pakan yang diberikan dikurangi dengan sisa pakan dalam selang waktu 24 jam. Pengukuran PBBH sapi induk dilakukan dengan mengurangkan bobot badan pada saat akhir penelitian dengan bobot badan awal dibagi dengan lama waktu pemeliharaan (hari). Data yang diperoleh dianalisis dengan analisis ragam (uji F), apabila hasil uji F menunjukkan hasil yang lebih besar dari $\mathrm{F}$ tabel, berarti ada perbedaan yang nyata antar perlakuan, dan dilanjutkan dengan uji Duncan.

\section{HASIL DAN PEMBAHASAN}

\section{Konsumsi Pakan}

Rata-rata konsumsi pakan yang meliputi konsumsi bahan kering (BK), konsumsi protein kasar (PK) dan konsumsi total digestible nutrient (TDN) pada sapi induk PO dan SPO selama penelitian seperti tersaji pada Tabel 2. Rata-rata konsumsi BK maupun rata-rata konsumsi BK dalam persentase bobot badan pada sapi induk PO maupun SPO perlakuan T0, T1 dan T2 sudah memenuhi standar kebutuhan BK sapi dewasa menurut Kearl (1982), yang menyatakan bahwa standar kebutuhan BK untuk sapi dewasa adalah $2,5 \%$ bobot badan.

Bangsa sapi tidak berpengaruh nyata $(\mathrm{P}>0,05)$ terhadap konsumsi $\mathrm{BK}$. Hal ini karena sapi induk PO mempunyai kemampuan untuk menggunakan pakan dengan optimal (Baliarti et al.2014) serta mempunyai kemampuan dalam memanfaatkan pakan berkualitas rendah (Adiwinarti et al. 2010), ,sehingga meskipun ukuran tubuh/bobot tubuhnya lebih kecil daripada sapi induk SPO, kemampuan mengkonsumsi BK sapi induk PO tidak berbeda dengan sapi induk SPO.

Hasil analisis statistik menunjukkan bahwa perlakuan ransum berpengaruh nyata $(\mathrm{P}<0,05)$ terhadap konsumsi $\mathrm{BK}$ maupun konsumsi BK dalam persentase bobot badan. Konsumsi BK baik pada sapi induk PO maupun SPO antara T0, T1 dan T2 berbeda nyata (Tabel 2).

Tabel 2. Rata-rata Konsumsi BK pada Sapi Induk PO dan SPO yang Mendapat Perlakuan Ransum

\begin{tabular}{|c|c|c|c|c|c|c|c|c|c|}
\hline \multirow[b]{2}{*}{ Perlakuan } & \multicolumn{3}{|c|}{ Konsumsi BK } & \multicolumn{3}{|c|}{ Konsumsi PK } & \multicolumn{3}{|c|}{ Konsumsi TDN } \\
\hline & $\mathrm{PO}$ & SPO & $\begin{array}{c}\text { Rata- } \\
\text { rata }\end{array}$ & $\mathrm{PO}$ & SPO & $\begin{array}{c}\text { Rata- } \\
\text { rata }\end{array}$ & $\mathrm{PO}$ & SPO & $\begin{array}{c}\text { Rata- } \\
\text { rata }\end{array}$ \\
\hline & & & & & $(\mathrm{kg}$ & & & & 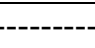 \\
\hline T0 & $7,15^{\mathrm{d}}$ & $8,31^{\mathrm{c}}$ & 7,73 & $0,89^{\mathrm{d}}$ & $1,04^{\mathrm{c}}$ & 0,97 & $3,90^{\mathrm{d}}$ & $4,54^{\mathrm{c}}$ & 4,22 \\
\hline $\mathrm{T} 1$ & $8,40^{\mathrm{c}}$ & $9,48^{\mathrm{b}}$ & 8,94 & $1,05^{\mathrm{c}}$ & $1,18^{\mathrm{b}}$ & 1,12 & $4,74^{\mathrm{c}}$ & $5,37^{\mathrm{b}}$ & 5,06 \\
\hline $\mathrm{T} 2$ & $9,66^{b}$ & $10,64^{\mathrm{a}}$ & 10,15 & $1,20^{\mathrm{b}}$ & $1,31^{\mathrm{a}}$ & 1,26 & $5,59^{b}$ & $6,22^{\mathrm{a}}$ & 5,91 \\
\hline \multirow[t]{2}{*}{ Rata-rata } & $8,40^{\mathrm{A}}$ & $9,48^{\mathrm{A}}$ & 8,94 & $1,05^{\mathrm{A}}$ & $1,18^{\mathrm{A}}$ & 1,12 & $4,74^{\mathrm{A}}$ & $5,38^{\mathrm{A}}$ & 5,06 \\
\hline & \multicolumn{3}{|c|}{----(\% bobot badan)----- } & & $-(\% \mathrm{BK})$ & $----\cdot-$ & & $-(\% \mathrm{BK}$ & --- \\
\hline T0 & $2,72^{\mathrm{cd}}$ & $2,54^{\mathrm{d}}$ & 2,63 & $12,48^{\mathrm{ac}}$ & $12,48^{\mathrm{ac}}$ & 12,48 & $54,60^{\mathrm{e}}$ & $54,60^{\mathrm{e}}$ & 54,60 \\
\hline $\mathrm{T} 1$ & $3,00^{\mathrm{b}}$ & $2,64^{\mathrm{cd}}$ & 2,82 & $12,50^{\mathrm{a}}$ & $12,41^{b c}$ & 12,46 & $56,40^{\mathrm{d}}$ & $56,63^{\mathrm{c}}$ & 56,52 \\
\hline $\mathrm{T} 2$ & $3,28^{a}$ & $2,78^{\mathrm{c}}$ & 3,03 & $12,40^{\mathrm{bc}}$ & $12,27^{\mathrm{d}}$ & 12,34 & $57,89^{\mathrm{b}}$ & $58,45^{\mathrm{a}}$ & 58,17 \\
\hline Rata-rata & $3,00^{\mathrm{A}}$ & $2,65^{\mathrm{A}}$ & 2,83 & $12,46^{\mathrm{A}}$ & $12,39^{\mathrm{A}}$ & 12,43 & $56,30^{\mathrm{A}}$ & $56,56^{\mathrm{A}}$ & 56,43 \\
\hline
\end{tabular}

Keterangan :

- Superskrip dengan huruf kecil yang berbeda pada baris dan kolom yang sama menunjukkan perbedaan nyata $(\mathrm{P}<0,05)$.

- Superskrip dengan huruf besar yang berbeda pada baris yang sama menunjukkan perbedaan nyata $(\mathrm{P}<0,05)$. 
Konsumsi BK paling tinggi pada perlakuan T2 (konsentrat 1\% BB), kemudian T1 (konsentrat $0,5 \% \mathrm{BB}$ ) dan paling rendah pada $\mathrm{T} 0$ (tanpa konsentrat). Hal ini diduga karena konsentrat yang diberikan merupakan bahan pakan yang memiliki palatabilitas dan kecernaan yang tinggi, sehingga pemberian konsentrat dapat meningkatkan konsumsi BK. Selain bobot badan, konsumsi BK ditentukan oleh palatabilitas dan kecernaan (Arora, 1995; Kearl, 1982). Hasil penelitian Quang et al. (2015) pada sapi Brahhman Cross juga menunjukkan bahwa suplementasi konsentrat meningkatkan konsumsi pakan $(\mathrm{P}<0,0001)$.

Palatabilitas adalah tingkat penerimaan ternak terhadap sesuatu bahan untuk dimakan, dan jumlah konsumsi pakan biasanya dianggap menggambarkan palatabilitas ternak terhadap pakan tersebut (Srigandono, 1991). Tidak adanya sisa pakan konsentrat yang diberikan pada sapi induk PO maupun SPO (perlakuan T1 dan T2) selama penelitian berlangsung, menunjukkan bahwa konsentrat mempunyai palatabilitas yang tinggi. Palatabilitas dicerminkan oleh sifat-sifat bahan pakan seperti kenampakan, bau, rasa (hambar, manis, asin, pahit) dan tekstur (Forbes, 1986). Palatabilitas pakan konsentrat yang tinggi diduga karena teksturnya yang lebih halus dibandingkan dengan pakan berserat, sehingga lebih mudah dikonsumsi, juga karena rasanya disukai oleh sapi.

Konsentrat merupakan bahan pakan yang mempunyai kandungan serat kasar rendah, sehingga kecernaannya tinggi. Bahan pakan dengan kecernaan yang tinggi akan meningkatkan konsumsi BK, sebab pakan akan lebih cepat dicerna dan gerak laju pakan dalam saluran pencernaan lebih cepat sehingga dapat segera tersedia ruang dalam saluran pencernaan untuk pakan yang baru (Parakkasi, 1999). Pakan yang digunakan pada perlakuan $\mathrm{T} 0$ hanya berupa jerami padi fermentasi dan rumput gajah yang merupakan bahan pakan berserat dengan kandungan serat kasar yang tinggi, sehingga kecernaannya rendah. Konsumsi pakan yang memiliki kecernaan rendah menyebabkan ternak tidak cepat merasa lapar, karena gerak laju pakan dalam saluran pencernaan lambat (Parakkasi, 1999). Konsumsi BK pada T2 yang lebih tinggi dibandingkan dengan T1 disebabkan level konsentrat pada T2 lebih banyak.

Konsumsi BK dalam persentase bobot badan pada sapi induk PO berbeda nyata antara T0, T1 dan T2 $(\mathrm{P}<0,05)$. Konsumsi BK dalam persentase bobot badan pada sapi induk SPO antara T0 dengan $\mathrm{T} 2$ berbeda nyata $(\mathrm{P}<0,05)$, tetapi antara T0 dengan $\mathrm{T} 1$ dan antara $\mathrm{T} 1$ dengan T2 tidak berbeda nyata $(\mathrm{P}>0,05$. Pemberian konsentrat meningkatkan konsumsi BK dalam persentase bobot badan pada sapi induk PO maupun SPO, sebab pemberian konsentrat dapat meningkatkan konsumsi $\mathrm{BK}$, sehingga akan meningkatkan konsumsi BK dalam persentase bobot badan.

Rata-rata konsumsi PK pada sapi induk PO dan SPO seperti tersaji pada Tabel 2. Konsumsi PK pada semua perlakuan baik pada sapi induk PO maupun SPO, dengan persentase PK terkonsumsi berdasarkan BK ransum antara 12,27 dan $12,50 \%$ sudah mencukupi kebutuhan harian untuk sapi induk menurut standar kebutuhan dari Kearl (1982), dan persentase protein kasar dalam ransum menurut Laven dan Drew (1999) berkisar antara $10-21 \%$. Kandungan protein dalam ransum sapi potong induk penting untuk diperhatikan, sebab kekurangan ataupun kelebihan protein dalam ransum akan berpengaruh terhadap penampilan reproduksi sapi induk. Sefa Salo (2018) menyatakan bahwa kekurangan protein dalam ransum sapi induk mengakibatkan menurunnya penampilan reproduksi. Menurut Gunn (2016), pembatasan protein dalam ransum sapi induk mengakibatkan meningkatnya service per conception dan lebih panjangnya calvig interval, sedangkan kelebihan protein dalam ransum sapi induk dapat menekan fertilitas terutama karena meningkatnya konsentrasi urea yang berdampak terhadap fungsi reproduksi.

Hasil penelitian Jordan dan Swanson (1979) pada sapi perah berproduksi tinggi (> $30 \mathrm{~kg}$ susu/hari) yang diberi ransum secara ad libitum dengan kandungan TDN 74,00\% dan kandungan PK 12,70; 16,30; dan 19,30\% menunjukkan bahwa days open dan S/C sapi perah induk yang diberi ransum dengan kandungan PK 12,70\% lebih baik daripada sapi perah induk yang diberi ransum dengan kandungan PK 16,30 dan 19,30\%. Hasil penelitian sejenis yang dilakukan oleh Canfield et al. (1990) menunjukkan bahwa S/C pada sapi perah induk yang diberi ransum dengan kandungan PK 16,00\% lebih baik daripada sapi perah induk yang diberi ransum dengan kandungan PK 19,00\%. Kandungan PK ransum yang terlalu tinggi (19\% dari BK ransum) dapat menyebabkan kadar urea dan amonia dalam darah yang terlalu tinggi, yang selanjutnya dapat menyebabkan $\mathrm{pH}$ saluran reproduksi yang terlalu tinggi, sehingga dapat menurunkan fertilitas (Jordan dan Swanson, 1979; Canfield et al., 1990; Qureshi et al., 2002). 
Berdasarkan hasil analisis statistik terlihat bahwa bangsa sapi tidak berpengaruh nyata $(\mathrm{P}>0,05)$ terhadap konsumsi PK maupun konsumsi PK dalam persentase BK ransum. Pengaruh bangsa sapi yang tidak nyata terhadap konsumsi PK maupun konsumsi PK dalam persentase BK ransum disebabkan konsumsi BK pada sapi induk PO tidak berbeda nyata dengan sapi induk SPO, selain itu bahan pakan yang digunakan pada kedua bangsa sapi tersebut adalah samaPerlakuan ransum berpengaruh nyata $(\mathrm{P}<0,05)$ terhadap konsumsi PK. Hasil uji Duncan menunjukkan bahwa konsumsi PK antara T0, T1 dan T2 pada sapi induk PO maupun SPO berbeda nyata). Hal ini karena pemberian konsentrat dapat meningkatkan konsumsi BK. Meningkatnya konsumsi BK menyebabkan meningkatnya konsumsi PK, karena bahan penyusun konsentrat maupun komposisi kimia bahan penyusun konsentrat pada $\mathrm{T} 1$ dan $\mathrm{T} 2$ adalah sama, yang berbeda hanya kuantitasnya.

Perlakuan ransum berpengaruh nyata $(\mathrm{P}<0,05)$ terhadap konsumsi $\mathrm{PK}$ dalam persentase BK ransum. Hasil uji Duncan menunjukkan bahwa konsumsi PK dalam persentase BK ransum pada sapi induk $\mathrm{PO}$ antara $\mathrm{T} 0$ tidak berbeda nyata dengan $\mathrm{T} 1$ dan $\mathrm{T} 2(\mathrm{P}>0.05)$, tetapi $\mathrm{T} 1$ berbeda nyata $(\mathrm{P}<0.05)$ dengan $\mathrm{T} 2$. Hal ini karena konsumsi jerami padi fermentasi pada T1 lebih tinggi daripada T0 dan T2.Konsumsi PK dalam persentase BK ransum pada sapi induk SPO antara $\mathrm{T} 0$ dan $\mathrm{T} 1$ berbeda nyata $(\mathrm{P}<0.05)$ dengan $\mathrm{T} 2$, dan antara $\mathrm{T} 0$ dan $\mathrm{T} 1$ tidak berbeda nyata $(\mathrm{P}>0.05$. Hal ini karena konsumsi jerami padi fermentasi pada sapi induk SPO menurun dengan pemberian konsentrat. Penurunan konsumsi jerami padi fermentasi berpengaruh terhadap menurunnya konsumsi PK dalam persentase BK ransum sebab kadar PK jerami padi fermentasi $(13,81 \%)$ lebih tinggi daripada kadar PK konsentrat (11,82\%).

Konsumsi TDN pada semua perlakuan baik pada sapi induk PO maupun SPO sudah mencukupi kebutuhan TDN yang diperlukan oleh sapi induk menurut standar kebutuhan dari Kearl (1982). Bangsa sapi tidak berpengaruh nyata $(\mathrm{P}>0,05)$ terhadap konsumsi TDN maupun konsumsi TDN dalam persentase BK ransum. Hal ini karena konsumsi BK pada kedua bangsa sapi tersebut tidak berbeda nyata serta bahan pakan yang digunakan dalam penyusunan ransum pada kedua bangsa sapi tersebut juga sama.

Perlakuan ransum berpengaruh nyata $(\mathrm{P}<0,05)$ terhadap konsumsi TDN maupun konsumsi TDN dalam persentase BK ransum. Hasil uji Duncan menunjukkan bahwa konsumsi
TDN baik pada sapi induk PO maupun SPO antara $\mathrm{T} 0, \mathrm{~T} 1$ dan $\mathrm{T} 2$ berbeda nyata $(\mathrm{P}<0,05)$. Konsumsi TDN paling tinggi pada perlakuan T2, dan yang paling rendah pada perlakuan T0. Hal ini karena kadar serat kasar dalam ransum menurun dengan penambahan konsentrat. Kadar serat kasar dalam ransum terkonsumsi baik pada sapi induk PO maupun SPO paling tinggi adalah T0 dan paling rendah adalah $\mathrm{T} 2$.

Penambahan konsentrat mengakibatkan menurunnya kadar serat kasar ransum, sebab kadar serat kasar konsentrat (17,76\%) lebih rendah daripada kadar serat kasar jerami padi fermentasi $(22,81 \%)$ dan rumput gajah $(32,38 \%)$. Kadar serat kasar ransum yang semakin menurun menyebabkan konsumsi TDN semakin meningkat. Hal ini sesuai dengan hasil penelitian Al-Arif et al. (2017) pada sapi bahwa kualiatas ransum yang terdiri dari pakan berserat dan konsentrat lebih baik daripada ransum yang hanya mengandung pakan berserat saja. Ransum yang terdiri dari pakan berserat dan konsentrat mengandung protein kasar, bahan ekstrak tanpa $\mathrm{N}$ (BETN), energi tercerna dan TDN yang lebih tinggi, sedangkan kandungan serat kasar dan lemaknya lebih rendah.

Hasil uji Duncan menunjukkan bahwa konsumsi TDN dalam persentase BK ransum baik pada sapi induk PO maupun SPO berbeda nyata $(\mathrm{P}<0,05)$ antara T0, T1 dan T2. Konsumsi TDN dalam persentase BK ransum paling tinggi pada perlakuan $\mathrm{T} 2$, kemudian $\mathrm{T} 1$, dan yang paling rendah pada perlakuan T0. Hal ini karena penambahan konsentrat dapat meningkatkan konsumsi TDN, sehingga dengan meningkatnya konsumsi TDN, maka konsumsi TDN dalam persentase $\mathrm{BK}$ ransum juga meningkat.

\section{Pertambahan Bobot Badan Harian}

Rata-rata PBBH pada sapi induk PO dan SPO seperti tersaji pada Tabel 3. Rata-rata PBBH sapi induk PO maupun SPO paling tinggi pada perlakuan $\mathrm{T} 2$, dan paling rendah pada perlakuan T0. Hasil analisis statistk menunjukkan bahwa bangsa sapi tidak berpengaruh $(\mathrm{P}>0,05)$ terhadap rata-rata $\mathrm{PBBH}$. Pengaruh bangsa sapi yang tidak nyata terhadap rata-rata $\mathrm{PBBH}$ disebabkan konsumsi pakan (bahan kering, protein kasar, TDN) tidak berbeda antara sapi induk PO dan SPO. Perlakuan ransum berpengaruh sangat nyata $(\mathrm{P}<0,01)$ terhadap PBBH. Hasil uji Duncan menunjukkan bahwa PBBH sapi induk PO maupun SPO antara T0, T1 dan T2 berbeda sangat nyata $(\mathrm{P}<0.01)$. Hal ini karena pada pemberian ransum tanpa konsentrat (perlakuan T0) 
cenderung tidak memberikan pertambahan bobot badan, sedangkan pada penambahan konsentrat dalam ransum (perlakuan T1 dan T2) terjadi pertambahan bobot badan, dan pertambahan bobot badan pada T2 lebih tinggi daripada T1 karena konsumsi zat pakannya lebih tinggi, antara lain dapat dilihat dari konsumsi protein kasar dan konsumsi TDN (Tabel 2) yang lebih tinggi pada T2 daripada T1 karena penambahan konsentratnya lebih tinggi.

Tabel 3. Rata-rata PBBH sapi induk PO dan SPO yang mendapat perlakuan ransum

\begin{tabular}{cccc}
\hline Perlakuan & PO & SPO & Rata-rata \\
\hline T0 & $0,02^{\mathrm{c}}$ & $0,01^{\mathrm{c}}$ & 0,015 \\
T1 & $0,31^{\mathrm{b}}$ & $0,26^{\mathrm{b}}$ & 0,285 \\
T2 & $0,48^{\mathrm{a}}$ & $0,50^{\mathrm{a}}$ & 0,490 \\
\hline Rata-rata & $0,27^{\mathrm{A}}$ & $0,26^{\mathrm{A}}$ & 0,265 \\
\hline
\end{tabular}

Keterangan : Superskrip dengan huruf kecil yang berbeda pada baris dan kolom yang sama menunjukkan perbedaan nyata $(\mathrm{P}<0,01)$.

Ransum T0 diduga hanya mampu untuk memenuhi kebutuhan hidup pokok. Ransum dengan penambahan konsentrat mempunyai TDN yang lebih tinggi dibandingkan tanpa konsentrat. Konsumsi TDN yang tinggi akan memberikan suplai energi yang tinggi. Menurut Huda (2018), suplai energi yang cukup sangat penting untuk kebutuhan hidup pokok dan produktifitas ternak, namun pemberiannya harus tetap berimbang dengan nutrisi yang lain seperti protein dan mineral. Tingkat energi dapat mempengaruhi tingkat pertambahan bobot badan (Parakkasi, 1999).

Sapi induk yang mendapat ransum T1 dan T2 mengalami keseimbangan energi positif, artinya pakan yang dikonsumsi selain dapat mencukupi kebutuhan tubuhnya, juga terdapat kelebihan zat pakan yang dikonsumsi yang dialokasikan untuk pertambahan bobot badan. Pertambahan bobot badan pada tahap ini dapat memperbaiki kondisi tubuh setelah partus dan menyusui. Menurut hasil penelitian Affandhy et al. (2019), terjadi penurunan skor kondisi tubuh dan bobot badan pada empat kelompok perlakuan waktu perkawinan sapi induk PO (perkawinan < 60 hari pasca beranak; 60 - 90 hari pasca beranak; $90-120$ hari pascaberanak dan $>120$ hari pasca beranak), yang dipengaruhi oleh nilai gizi dan konsumsi pakan induk. Hasil penelitian Christopher (2004) juga menunjukkan bahwa sapi induk pada bulan ke-1 sampai ke-4 setelah beranak mengalami penurunan bobot badan rata- rata $0,35 \pm 0,21 \mathrm{~kg} /$ hari (pada PO) dan 0,63 $\pm 0,31$ $\mathrm{kg} / \mathrm{hari}$ (pada SPO). Diharapkan dengan adanya pertambahan bobot badan pada tahap ini kondisi tubuh sapi induk tidak terlalu kurus, sehingga fertilitas induk dapat lebih baik. Hasil penelitian de Sousa Sales et al. (2019) pada sapi potong induk menunjukkan bahwa suplementasi energi dan protein 12 hari sebelum inseminasi buatan cukup dapat meningkatkan fertilitasnya.

\section{Skor Kondisi Tubuh}

Penilaian BCS merupakan salah satu metode untuk mengukur tingkat perlemakan pada sapi induk dengan menggunakan skor. Hasil penilaian BCS pada sapi bersifat obyektif dan tidak dapat dikaitkan dengan bobot hidup sapi, oleh karena itu antara ternak sapi yang memiliki bobot hidup sama, nilai BCS nya belum tentu sama.

Tabel 4. Rata-rata Skor Kondisi Tubuh (BCS) Sapi Induk PO dan SPO yang Mendapat Perlakuan Ransum

\begin{tabular}{cccc}
\hline Perlakuan & PO & SPO & Rata-rata \\
\hline T0 & 1,44 & 1,63 & $1,53^{\mathrm{a}}$ \\
T1 & 2,44 & 1,94 & $2,19^{\mathrm{b}}$ \\
T2 & 2,88 & 2,88 & $2,88^{\mathrm{c}}$ \\
\hline Rata-rata & $2,25^{\mathrm{A}}$ & $2,15^{\mathrm{A}}$ & 0,265 \\
\hline
\end{tabular}

Keterangan : Superskrip dengan huruf kecil yang berbeda pada kolom yang sama menunjukkan perbedaan nyata $(\mathrm{P}<0,01)$.

Berdasarkan Tabel 4, BCS paling tinggi pada sapi-sapi perlakuam T2, kemudian T1 dan paling rendah pada perlakuan T0. Hasil analisis statistik menunjukkan bahwa bangsa sapi tidak berpengaruh $(\mathrm{P}>0.05)$ terhadap BCS, sedangkan perlakuan ransum berpengaruh sangat nyata $(\mathrm{P}<0,01)$ terhadap BCS. Hasil analisis statistik ini senada dengan hasil analisis statistik pada pertambahan bobot badan. BCS sapi induk pada perlakuan ransum T2 paling tinggi diduga karena sapi-sapi induk pada kelompok ini mendapatkan asupan nutrien paling tinggi, khususnya karbohidrat dan protein.

Hal ini sesuai dengan pernyataan Neumann dan Lusby (1986) bahwa sapi yang memiliki BCS yang bagus memiliki perlemakan dan perototan yang lebih besar sebagai akibat dari pakan yang baik. Menurut Hickson dan Morris (2017), periode terpenting pada sapi potong induk dalam setiap tahunnya adalah dari beranak sampai dikawinkan kembali. Peningkatan BCS selama periode ini akan mendapatkan pedet lepas sapih 
yang bagus dan meningkatkan peluang memasuki periode kebuntingan yang lebih awal. Jika sapi betina gagal mencapai target BCS pada saat dikawinkan, maka perkawinan akan tertunda, produksi susu induk dan laju pertumbuhan pedet akan menurun yang berakibat pada bobot sapih pedet yang lebih kecil. Berdasarkan Tabel 4 diatas, kelompok sapi pada perlakuan $\mathrm{T} 1$ dan $\mathrm{T} 2$ memiliki BCS sapi yang cukup, karena untuk dapat berfungsinya sistem reproduksi, BCS sapi induk seharusnya diatas atau sama dengan 2 dari skala 1 - 5 (Ditjenak, 2016). Kelompok sapi induk pada perlakuan T2 mempunyai BCS paling ideal seperti pendapat Tophianong et al. (2014) bahwa BCS ideal dari sapi betina yang akan di IB adalah $2,5-3$ dari skala $1-5$.

\section{KESIMPULAN}

Pemberian konsentrat dengan kadar protein kasar 11,82\% dan TDN 66,74\% sebanyak $0,5 \%$ dan $1 \%$ dari bobot badan pada sapi induk PO dan sapi induk silangan Simmental - PO dapat memperbaiki BCS sapi induk. Pemberian konsentrat dengan kadar protein kasar 11,82\% dan TDN $66,74 \%$ sebanyak $1 \%$ dari bobot badan dapat dianjurkan untuk sapi induk PO dan sapi induk silangan Simmental - PO pada saat menjelang dikawinkan. Perlu adanya penelitian lebih lanjut mengenai perbaikan pakan sapi induk pasca beranak dengan pemberian konsentrat terhadap penampilan reproduksinya antara lain intensitas estrus, lama estrus, siklus estrus nonreturn rate, conception rate dan service per conception dan lain-lain.

\section{DAFTAR PUSTAKA}

Affandhy, L., D. M. Dikman dan D. Ratnawati. 2019. Pengaruh Waktu Perkawinan Pasca Beranak Terhadap Performa Produktivitas Sapi Induk pada Kondisi Peternakan Rakyat. Jurnal Ilmu-Ilmu Peternakan 29 (2) : $158-166 . \quad$ DOI : https://doi.org/10.21776/ub.jiip.2019.029.0 2.07

Al-Arif, M. A., Lucia Tri Suwanti, A. T. Soelih Estoepangesti and Mirni Lamid. 2017. The Nutrient Contents, Dry Matter Digestibility, Organic Matter Digestibility, Total Digestible Nutrients, and NH3 Rumen Production of Three Kinds of Cattle Feeding Models. The Veterinery Medicine International Conference 2017, KnE Life
Sciences, pages 338-343. DOI: https://doi.org/10.18502/kls.v3i6.1142

Adiwinarti, R., C. M. S. Lestari and D. K. Widyastuti. 2010. Efisiensi Penggunaan Pakan Jerami Padi dan Konsentrat pada Sapi Peranakan Ongole (PO) dan Peranakan Friesian Holstein (PFH). Proceedings, Seminar Nasional Perspektif Pengembangan Agribisnis Peternakan di Indonesia. Faculty of Animal Husbandry. Jenderal Soedirman University, 10 April 2010 : 177-181.

Arora, S. P. 1995. Pencernaan Mikroba pada Ruminansia. Gajah Mada University Press. Yogyakarta. (Diterjemahkan oleh R. Murwani).

Baliarti, E, F. Ariyanti, Ismaya, N. Ngadiyono, I G. S. Budisatria and Panjono. 2014. Performace Ongole Grade and Simmental Ongole Crossbred Cow at Village Breeding Center at Special Region Yogyakarta, Indonesia. Proceedings of the 16th AAAP Animal Science Congress Vol. II, Gadjah Mada University, Yogyakarta, Indonesia : $900-903$.

Canfield, R. W., C. J. Sniffen and W. R. Butler. 1990. Effects of excess degradable protein on postpartum reproduction and energy balance in dairy cattle. J. Dairy Sci. 73 : 2342-2349.

Christopher, W. T. H, 2004. Kinerja Induk Sapi Silangan Simmental-Peranakan Ongole dan Peranakan Ongole Periode Prepartum Sampai Post Partum di Kecamatan Bambanglipuro Kabupaten Bantul. Program Pasca Sarjana UGM, Yogyakarta. (Tesis Magister Pertanian).

de Sousa Sales, J. N., L. M. Souza Simoes, R. E. Orlandi, E. A. Lima, A. P. Castro Santos, M. P. Bottino, L. A. C. Leite da Silva, J. C. de Souza, M. Marona Diaz, J. P. M. Massoneto, L. A. Scandiuzzi Jr., B. G. Freitaz, B. M. Guerreiro and M. R. Bartos. 2019. Pre-TAI Protocol Strategies to Increase Reproductive Efficiency in Beef and Dairy Cows. Anim. Reprod. 16 (3) : 402-410, Jul./Sept. 2019 DOI: https://doi.org/ 10.21451/1984-3143ar2019-0041

Ditjenak. 2016. Pedoman Teknis Gangguan Reproduksi (Gangrep) 2017. Direktorat 
Jenderal Peternakan dan Kesehatan Hewan

- Kementerian Pertanian. Jakarta.

Edmonson, A. J., I. J. Lean, L. D.Weaver, T. Farver, G. Webster. 1989. A body condition scoring chart for Holstein dairy cows. J. Dairy Sci. 72: 68-78.

Forbes, J. M. 1986. The Voluntary Food Intake of Farm Animals. (C) Butterworths \& Co., London.

Huda, A. N., Mashudi, Kuswati, T. Susilowati, S. Wahyuningsih, N. Isnaini, A. Y. Puspita dan A. T. Satria. 2018. Evaluasi Kecukupan Nutrisi Induk Sapi Potong di Desa Leran Wetan dan Leran Kulon, Kecamatan Palang, Kabupaten Tuban. J. Ternak Tropika 19 (2): 111 - 119. DOI: https://doi.org/10.21776/ub.jtapro.2018.01 9.02.6

Laven, R. A. and S. B. Drew. 1999. Dietary Protein and the Reproductif Performance of Cow. Veterinery Record $145: 687-695$.

NFACC, 2013. Code of Practice for the Care and Handling of Beef Cattle.

Neumann, A. L and K. S Lusby. 1986. Matching Cow Productivity and Resources. Chapter 3. Beef Cattle (Eighth Ed.). Sapi Potong. John Wiley and Sons, Inc., New York. John Wiley and Sons, Inc, New York.

Hickson, R dan S. Morris. 2017. Beef Cow Body Condition Scoring. Landcorp - New Zealand.

Jordan, E. R. and L. V. Swanson. 1979. Effect of crude protein on reproductive efficiency, serum total protein, and albumin in the high producing dairy cow. J. Dairy Sci. $62: 56$ 63.

Kaps, M. and W. Lamberson, 2007. Biostatistics for Animal Science. CABI Publishing. Cromwell Press, Trowbridge.

Kearl, L. C. 1982. Nutrient Requirements of Ruminant in Developing Countries.
International Feedstuff Institute Utah Agriculture Experiment Station. Utah State University, Logan.

Parakkasi, A. 1999. Ilmu Nutrisi dan Makanan Ternak Ruminan. Penerbit Universitas Indonesia, Jakarta.

Quang, D. V., N. X. Ba, P. T. Doye, D. V. Hai, A. Peter, L. Aduli, E. O. Malau-Aduli, N. H. Van and D. Parsons. 2015. Effect of Concentrate Suplementation on Nutrient Digestibility and Growth of Brahman Crossbred Fed of Basal Fed a Basal Diet of Grass of Rice Straw. Journal of Animal Science and Technology 57 : 35 DOI: https://doi.org/10.1186/s40781-015-0068-y

Qureshi, M. S., G. Habib, H. A. Samad, M. M. Siddiqui, N. Ahmad and M. Syed. 2002. Reproduction-nutrition relationship in dairy buffaloes. I. Effect of intake of protein, energy and blood metabolites levels. Asian-Aust. J. Anim. Sci. 15 (3) : 330-339.

Sefa Salo. 2018. Effects of Quality of Amounts of Dietary Protein on Dairy Cattle Reproduction and the Environtment. Dairy and Sci. J. 5 (5) : DOI: https://doi.org/10.19080/JDVS.2018.05.55 5675

Tophianong, T. C., B. Agung, dan E. N. Maha. 2014. Tinjauan Hasil Inseminasi Buatan Berdasarkan Anestrus Pasca Inseminasi pada Peternakan Rakyat Sapi Bali di Kabupaten Sikka Nusa Tenggara Timur. Jurnal Sain Veteriner 32 (1) : 46 - 54.

Wright, I. A, S. M. Rhind, A. J. F. Russel, T. K.Whyte, A. J. Mcbean, and S. R. Mcmillen. 1987. Effects of body condition, food intake and temporary calf separation on the duration of the post-partum anestrus period and associated LH, FSH and prolactin concentration in beef cows. Anim. Prod. 45: 395-402. 